\title{
PENGAWASAN DEWAN PERWAKILAN RAKYAT DAERAH TERHADAP PELAKSANAAN PERATURAN DAERAH BERDASARKAN UNDANG- UNDANG NOMOR 32 TAHUN 2004 TENTANG PEMERINTAHAN DAERAH
}

\author{
Kartika Winkar Setya \\ Magister Ilmu Hukum Fakultas Hukum Universitas Jenderal Soedirman
}

\begin{abstract}
Indonesia is a unitary state which is divided into provincial areas which are further subdivided into areas of the district/city based on the principle of regional autonomy. The existence of local regulation is very important, but unfortunately there are a variety of problematic regulations that live in the society, either because it does not conform with the conditions of the society or for not complying with legislation is another. Local regulations are problematic it can be minimized by monitoring function held by Parliament, as mentioned in Article 42 paragraph (1) letter c of Act No. 32 of 2004 which stipulates that Parliament has the duty and authority to supervise the implementation of local regulations. Supervision by the Provincial Council and District Council carried out local regulation on the implementation by the Act 32 of 2004 uses the concept of supervision in the narrow sense that focused on matching between rules and their implementation in the field. Parliament in the means used to supervise the implementation of regulations in general through the implementation of the rights of Parliament, implementation consulting, receiving complaints and aspirations of the people. Yet there are clear arrangements regarding the parameters of supervision, monitoring and corrective action mechanisms of monitoring the implementation by the parliament.
\end{abstract}

Keyword: local governments, local regulations, supervision

\begin{abstract}
Abstrak
Indonesia adalah negara kesatuan yang terbagi menjadi wilayah-wilayah provinsi yang kemudian dibagi lagi menjadi wilayah-wilayah kabupaten/kota berdasarkan asas otonomi daerah. Produk hukum yang menjadi pedoman pelaksanaan pemerintahan di daerah salah satunya berupa peraturan daerah (perda). Keberadaan perda menjadi sangat penting, namun sangat disayangkan masih terdapat berbagai perda bermasalah yang hidup dalam masyarakat, baik karena sudah tidak sesuai dengan kondisi masyarakat atau karena tidak sesuai dengan peraturan perundang-undangan yang lain. Perda-perda yang bermasalah tersebut dapatlah diminimalisir dengan fungsi pengawasan yang dimiliki oleh DPRD, sebagaimana disebutkan dalam Pasal 42 ayat (1) huruf c UU No. 32 tahun 2004 yang menentukan bahwa DPRD memiliki tugas dan wewenang untuk melakukan pengawasan terhadap pelaksanaan perda. Pengawasan yang dilakukan oleh DPRD Provinsi dan Kabupaten/Kota terhadap pelaksanaan Peraturan Daerah berdasarkan UU No. 32 Tahun 2004 menggunakan konsep pengawasan dalam arti sempit yang hanya menitikberatkan pada pencocokan antara peraturan dengan pelaksanaannya dilapangan. Sarana yang digunakan DPRD dalam melaksanakan pengawasan terhadap pelaksanaan perda secara umum melalui pelaksanaan hak-hak DPRD, pelaksanaan konsultasi, penerimaan pengaduan dan aspirasi masyarakat. Belum terdapat pengaturan yang jelas mengenai parameter pengawasan, mekanisme pengawasan dan tindakan korektif dari hasil evaluasi pelaksanaan pengawasan oleh DPRD.
\end{abstract}

Kata kunci: pengawasan, Pemerintah Daerah, Peraturan Daerah

\section{Pendahuluan}

Negara Indonesia adalah negara hukum sebagaimana termaktub dalam Pasal 1 ayat (3) UUD 1945, terkandung pengertian di dalamnya bahwa segala tindakan pemerintah harus didasarkan pada peraturan perundang-undangan dan dapat dipertanggung jawabkan di hadapan hukum. Indonesia adalah negara kesatuan yang terbagi menjadi wilayah provinsi yang kemudian dibagi lagi menjadi 
wilayah kabupaten/kota berdasarkan asas otonomi daerah. Pemerintah baik pusat maupun daerah dalam menjalankan segala tindakan pemerintahan wajib mendasarkan pada aturan hukum dan dapat dipertanggungjawabkan dihadapan hukum (prinsip negara hukum). Produk hukum yang menjadi pedoman pelaksanaan pemerintahan di daerah salah satunya berupa peraturan daerah (perda).

Penyelenggara pemerintahan daerah terdiri dari dua unsur yakni Dewan Perwakilan Rakyat Daerah (DPRD) dan Kepala Daerah, dengan kedudukan yang setara dan hubungan kerja kemitraan. Kedudukan yang setara dimaknai bahwa antara DPRD dan Kepala Daerah berada pada derajat yang sama (tidak saling membawahi). Kesetaraan kedudukan tersebut tercermin dalam proses pembuatan peraturan daerah. Kepala daerah bekerjasama dengan DPRD dalam menyusun dan merumuskan kebijaksanaan baik secara aktif maupun secara pasif. Secara aktif apabila sebagian besar pandangan kebijaksanaan berasal dari pemerintah, dan pasif manakala rumusan kebijaksanaan lebih banyak berasal dari pandangan anggota dewan. Kebijaksanaan tersebut dirumuskan kedalam suatu peraturan daerah dimana DPRD setelah menentukan dan menyetujui rumusan suatu kebijaksanaan, maka kemudian diserahkan kepada eksekutif (kepala daerah beserta jajarannya) untuk dilaksanakan.

Keberadaan perda menjadi sangat penting, namun sangat disayangkan masih terdapat berbagai perda bermasalah yang hidup dalam masyarakat, baik karena sudah tidak sesuai dengan kondisi masyarakat atau tidak sesuai dengan peraturan perundang-undangan yang lain. Pada tahun 2010, Kementerian Dalam Negeri (Kemendagri) juga telah melakukan evaluasi terhadap perda yang lahir sepanjang 2002-2009 menyebutkan dari 2.285 perda, sebanyak 407 perda se-Indonesia dinilai bermasalah. Perda tersebut nantinya akan dibatalkan oleh Kemendagri melalui Surat Keputusan (SK) Menteri Dalam Negeri. Lima besar

Lihat pada http://www.depdagri.go.id/basis-data/2010/03/ 05/daftar-perda-dan-kep-kdh-yang dibatalkan-thn-20022009, diunduh tanggal 15 Januari 2013, pukul 17.00 WIB provinsi yang paling banyak dibatalkan perdanya yaitu Sumatera Utara 180 perda, Jawa Timur 138 perda, Jawa Barat 115 perda, Sulawesi Selatan 97 perda, dan Jambi 94 perda. Selanjutnya, Jawa Tengah 86 perda, Kalimantan Timur 81 perda, Riau 80 perda, Kalimantan Tengah 75 perda, dan Sulawesi Tengah 68 perda. ${ }^{1}$

Melihat pada Pasal 42 (1) huruf UU No. 32 Tahun 2004 tentang Pemerintahan Daerah, bahwa DPRD mempunyai tugas dan wewenang untuk melaksanakan pengawasan terhadap pelaksanaan perda dan peraturan perundang-undangan lainnya, peraturan Kepala Daerah, APBD, kebijakan pemerintah daerah dalam melaksanakan program pembangunan daerah dan kerjasama internasional di daerah. Tugas dan wewenang tersebut mestinya dapat menjadi solusi untuk mengontrol keserasian terhadap pemberlakuan suatu perda dengan peraturan perundang-undangan di atasnya serta menjadi sarana perwujudan check and balances system.

\section{Perumusan masalah}

Pertama, bagaimana pengawasan DPRD terhadap pelaksanaan Peraturan Daerah berdasarkan Undang-Undang Nomor 32 Tahun 2004; Kedua, bagaimanakah konsep pengawasan yang tepat diterapkan terhadap pelaksanaan Peraturan Daerah pada masa yang akan datang.

\section{Metode penelitian}

Metode penelitian yang digunakan adalah yuridis normatif dengan pendekatan undangundang (statute approach) dan pendekatan konseptual (conceptual approach. Peneliti menggunakan data sekunder dan data primer untuk memperoleh hasil penelitian yang obyektif. Analisis data dalam penelitian ini menggunakan metode analisis data kualitatif. 


\section{Pembahasan}

Pengawasan pelaksanaan perda dalam kerangka Tatib DPRD Provinsi Sumatera Utara Nomor 5 tahun 2010.

Pengawasan oleh DPRD provinsi Sumatera Utara terhadap pelaksanaan perda dapat dilihat dalam Flowchart Pengawasan di bawah ini:

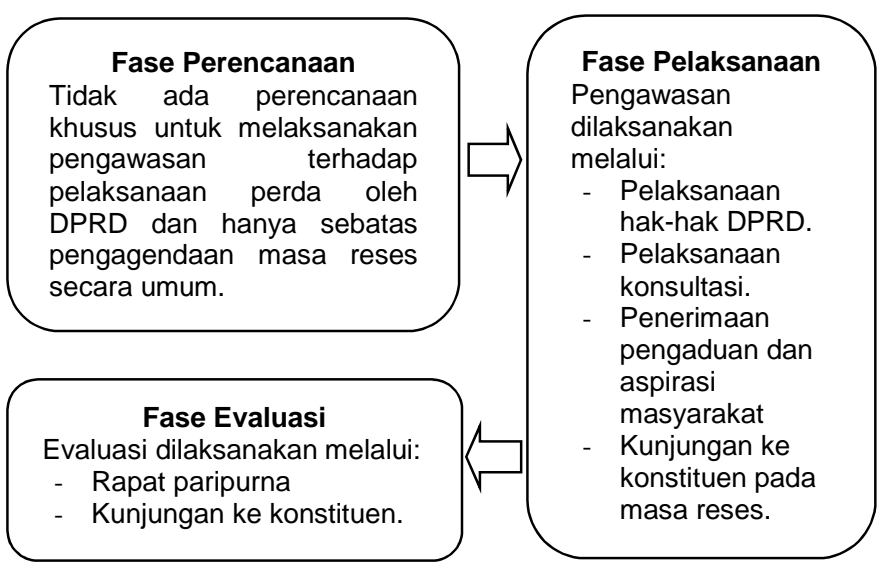

Gambar 1: pengawasan oleh DPRD provinsi Sumatera Utara.

Diolah dan dimodifikasi oleh Kartika Winkar Setya tahun 2013.

Adapun flowchart pelaksanaan pengawasan oleh DPRD Provinsi Sumatera Utara:

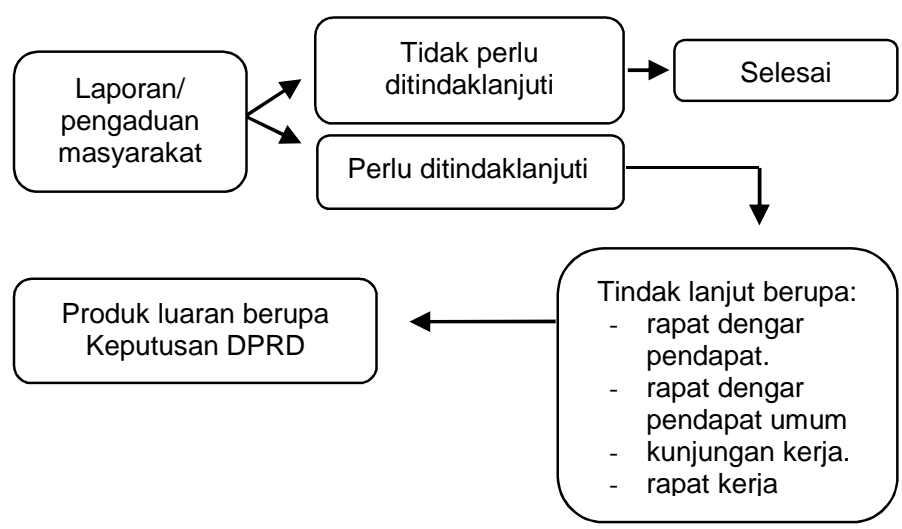

Gambar 2: Pelaksanaan Pengawasan Oleh DPRD provinsi Sumatera Utara.

Diolah dan dimodifikasi oleh Kartika Winkar Setya tahun 2013.

\section{Pengawasan Pelaksanaan Perda dalam Kerang- ka Tata Tertib DPRD Kabupaten Banyumas No- mor 1 tahun 2010. \\ Pengawasan terhadap pelaksanaan perda oleh DPRD Kabupaten Banyumas, sebagai berikut:}

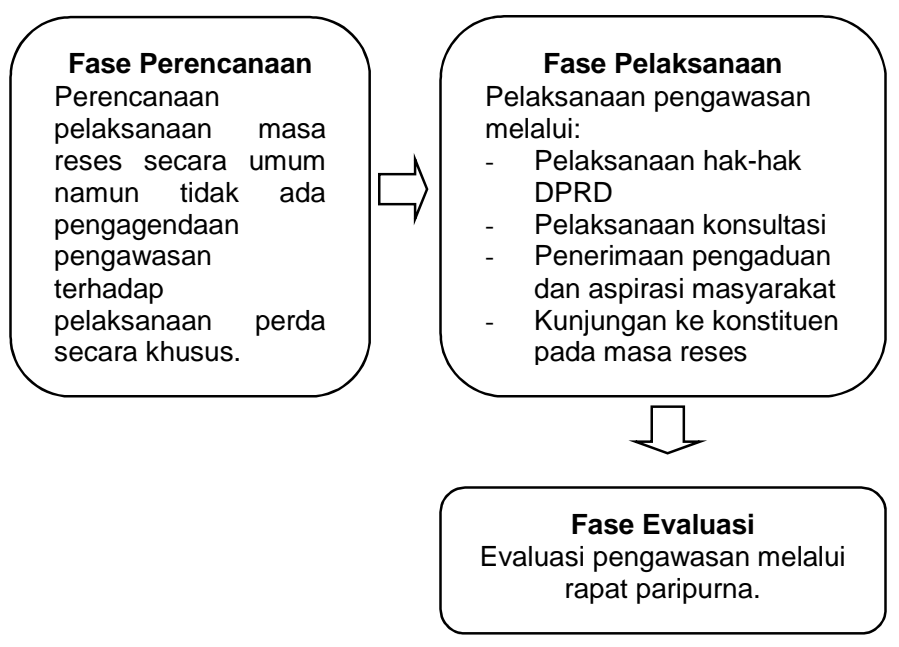

Gambar 3: Pengawasan oleh DPRD Kabupaten Diolah dan dimodifikasi oleh Kartika Winkar Setya tahun 2013

\section{Adapun flowchart mekanisme} pelaksanaan pengawasan terhadap pelaksanaan perda oleh DPRD Kabupaten Banyumas, sebagai berikut:

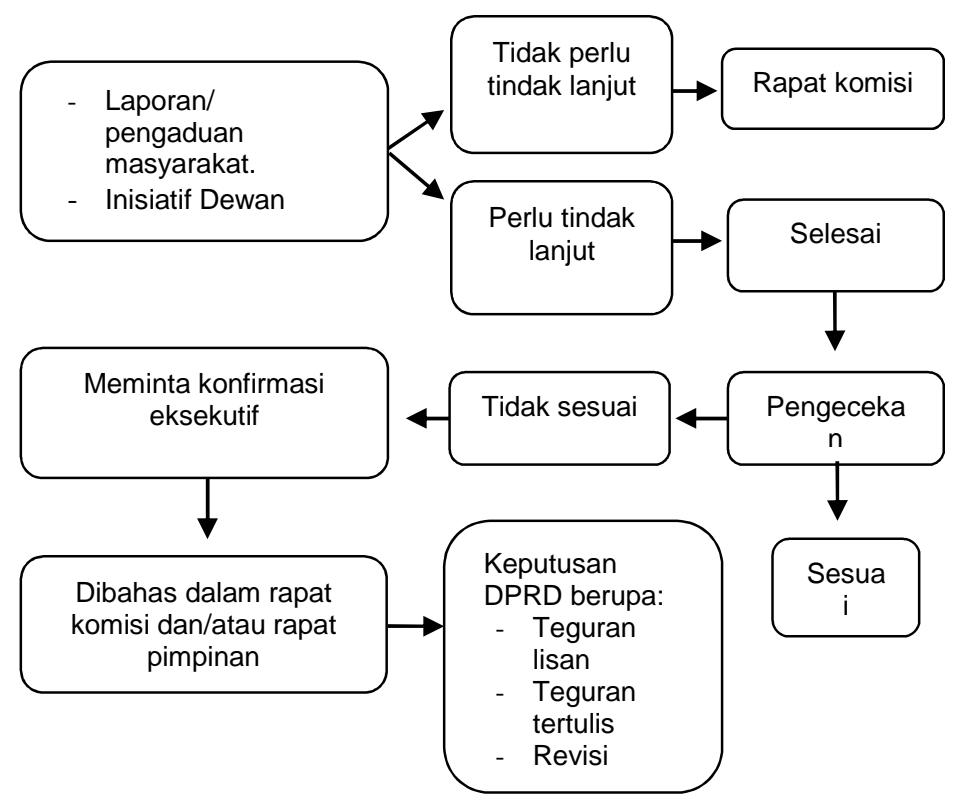


Gambar 4: Pelaksanaan pengawasan oleh DPRD Kabupaten Banyumas.

Diolah dan dimodifikasi oleh Kartika Winkar Setya tahun 2013

Pengawasan pelaksanaan perda yang telah dilakukan oleh DPRD Kabupaten Banyumas antaralain pengawasan terhadap Perda kabupaten Banyumas No. 4 Tahun 2003 tentang Pedagang Kaki Lima, yang kemudian dicabut dan digantikan dengan Perda Kabupaten Banyumas No. 4 Tahun 2011 tentang Penataan dan Pemberdayaan Pedagang Kaki Lima. Penggantian perda tersebut berawal dari inisiatif DPRD yang menangkap fenomena keberadaan pedagang kaki lima (PKL) yang semakin banyak memanfaatkan ruang publik di wilayah Kabupaten Banyumas dengan tidak tertib, hal tersebut dikeluhkan pula oleh sebagian masyarakat Banyumas.

Berpangkal dari permasalahan itu, kemudian diadakan rapat komisi yang ditindaklanjuti dengan pengecekan antara substansi dalam Perda Kabupaten Banyumas No. 4 tahun 2003 yang mengatur tentang PKL dengan pelaksanaannya dilapangan. Hasil dari pengecekan tersebut, selanjutnya dibahas dan dievaluasi dalam rapat komisi dan rapat pimpinan, yang kemudian menghasilkan keputusan DPRD untuk mencabut Perda No. 4 Tahun 2003 tentang Pedagang Kaki Lima diganti dengan Perda Kabupaten Banyumas No. 4 Tahun 2011 tentang Penataan dan Pemberdayaan Pedagang Kaki Lima. Adapun proses pengawasan Perda Kabupaten Banyumas No. 4 Tahun 2003 dapat digambarkan dalam flowchart, sebagai berikut:

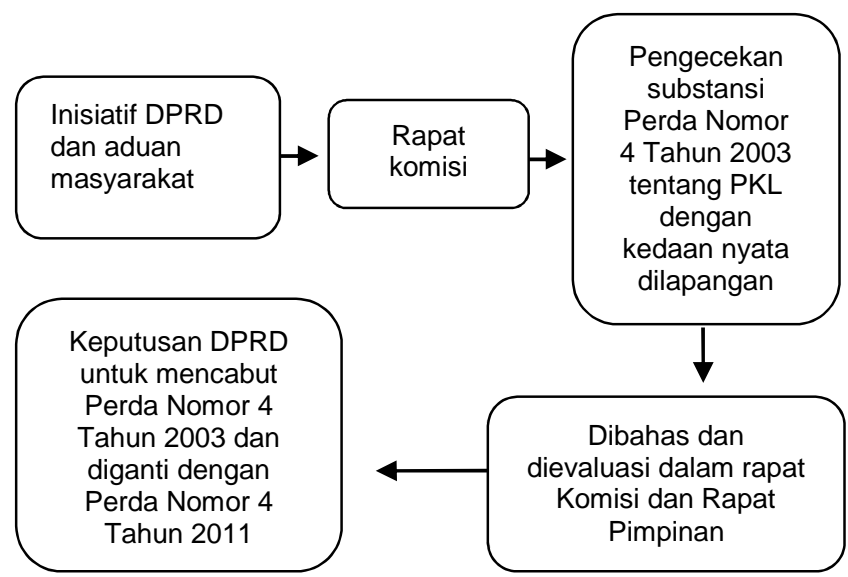

Gambar 5: Pengawasan terhadap pelaksanaan Perda Kabupaten Banyumas No. 4 Tahun 2003.

Diolah dan dimodifikasi oleh Kartika Winkar Setya tahun 2013

\section{Pengawasan oleh DPRD Provinsi Daerah Istimewa Yogyakarta dalam kerangka tata tertib DPRD Provinsi Daerah Istimewa Yogyakarta}

Pengawasan oleh DPRD Provinsi Daerah Istimewa Yogyakarta terhadap pelaksanaan perda, sebagai berikut:

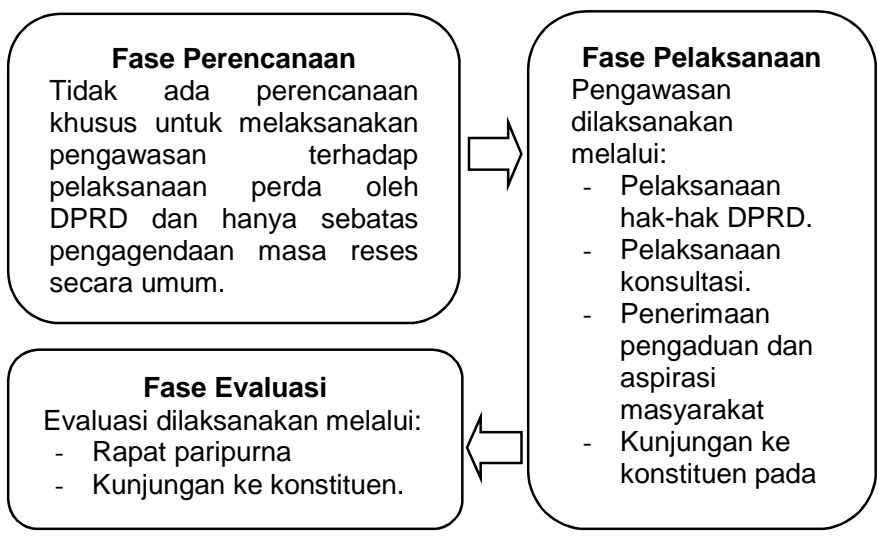

Gambar 6: Pengawasan oleh DPRD Provinsi DIY Diolah dan dimodofikasi oleh Kartika Winkar Setya tahun 2013

Keistimewaan dari norma pengawasan yang tertuang dalam peraturan tata tertib DPRD provinsi DIY dibandingkan dengan peraturan tata tertib provinsi Sumatera Utara adalah adanya pengaturan terkait dengan pengawasan diatur tersendiri dalam BAB XV Peraturan Tata Tertib DPRD provinsi DIY No. 1 Tahun 2010. Peraturan tata tertib DPRD Provinsi DIY dalam Pasal 99 mengatur pula mengenai kewajiban untuk menyusun laporan hasil pengawasan sehingga pelaksanaan dan perbaikannya kedepan akan terdokumentasi dengan baik dan teratur. Adapun flowchart pelaksanaan pengawasan, sebagai berikut: 


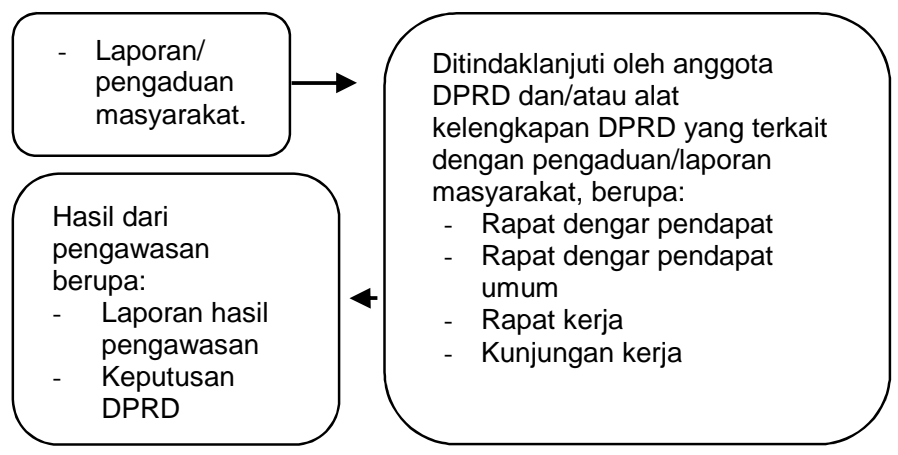

Gambar 7: Pelaksanaan pengawasan oleh DPRD Provinsi DIY

Diolah dan dimodofikasi oleh Kartika Winkar Setya tahun 2013.

Sejak munculnya UU No. 32 Tahun 2004 tentang pemerintahan Daerah sejatinya menjadikan Dewan Perwakilan Rakyat Daerah (DPRD) memiliki kedudukan yang unik dan cenderung dualistik. Ketentuan dalam Pasal 40 UU No. 32 Tahun 2004 menyebutkan bahwa DPRD merupakan lembaga perwakilan rakyat darah dan berkedudukan sebagai unsur penyelenggaraan pemerintahan daerah. Nampak disini bahwa DPRD menjadi unsur dari penyelenggara pemerintahan di daerah yakni sebagai mitra kerja dari kepala daerah untuk mencapai tujuannya. Hal ini menjamin terciptanya hubungan yang harmonis dan saling mendukung antara DPRD dengan pemerintah daerah (Kepala Daerah). Namun disisi lain, DPRD merupakan lembaga perwakilan rakyat yang menjalankan fungsi legislasi, anggaran dan pengawasan sebagai wujud representasi rakyat. DPRD diarahkan untuk dapat menyerap dan menyalurkan aspirasi masyarakat, serta menjadi salah satu mekanisme kontrol rakyat terhadap kinerja pemerintah daerah. Kedudukan DPRD yang unik secara langsung ataupun tidak, akan berdampak terhadap obyektifitas kinerja DPRD dalam hubungannya dengan pemerintah daerah termasuk dalam menjalankan fungsi pengawasan.

Pelaksanaan fungsi pengawasan DPRD telah diatur dalam Pasal 42 ayat (1) huruf c UU No. 12 Tahun 2008 tentang Perubahan Kedua Atas UU No. 32 Tahun 2004 tentang Pemerintahan Daerah, yang menentukan bahwa DPRD mempunyai tugas dan wewenang untuk melaksanakan pengawasan terhadap pelaksanaan perda dan peraturan perundang-undangan lainnya, peraturan Kepala Daerah, APBD, kebijakan pemerintah daerah dalam melaksanakan program pembangunan daerah dan kerjasama internasional di daerah.

Selain diatur dalam Pasal 42 ayat (1) huruf $\mathrm{c}$ UU No. 32 Tahun 2004, terkait pelaksanaan penga-wasan DPRD oleh DPRD provinsi diatur pula dalam ketentuan Pasal 293 UU No. 27 Tahun 2009 tentang Majelis Permusyawaratan Rakyat, Dewan Perwakilan Rakyat, Dewan Perwakilan Daerah, dan Dewan Perwakilan Rakyat Daerah, mengenai tugas dan wewenang DPRD Provinsi. DPRD kabupaten/kota memiliki tugas dan wewenang yang diatur dalam Pasal 344 UU No. 27 tahun 2009 antara lain melaksanakan pengawasan terhadap pelaksanaan perda dan anggaran pendapatan dan belanja daerah kabupaten/kota. Pengaturan mengenai pelaksanaan pengawasan DPRD kemudian diturunkan dalam Peraturan Pemerintah No. 16 Tahun 2010 tentang Pedoman Penyusunan Peraturan Dewan Perwakilan Rakyat Daerah tentang Tata Tertib Dewan Perwakilan Rakyat Daerah, yang dalam Pasal 3 menentukan tugas dan wewenang DPRD, salah satunya adalah melaksanakan pengawasan terhadap pelaksanaan peraturan daerah dan APBD.

Pengawasan menurut teori yang dikemukakan oleh Robert J.Mokler diartikan sebagai usaha sistematik untuk menetapkan standar pelaksanaan dengan tujuan-tujuan perencanaan, merancang sistem informasi maupun umpan balik, membandingkan kegiatan nyata dengan standar yang telah ditetapkan sebelumnya, menentukan dan mengukur penyimpangan-penyimpangan, serta mengambil tindakan koreksi yang diperlukan, bahwa semua sumber daya yang dipergunakan dengan cara yang paling efektif dan efisien dalam pencapaian tujuan.

Menurut teori yang dikemukakan oleh Robert J. Mokler apabila didialogkan terhadap data 1, data 2 dan data 3, maka dapat diinterpretasikan bahwa pengawasan DPRD terhadap pelaksanaan perda saat ini terbagi menjadi 3 fase meliputi fase 
perencanaan, pelaksanaan dan evaluasi yang mengandung unsur koreksi.

Unsur-unsur pengawasan menurut Muchsan dapat disimpulkan bahwa pengawasan memiliki beberapa unsur, yaitu: (1) Adanya kewenangan yang jelas yang dimiliki oleh aparat pengawas; (2) Adanya suatu rencana yang mantap sebagai alat penguji terhadap pelaksanaan suatu tugas yang akan diawasi; (3) Tindakan pengawasan dapat dilakukan terhadap suatu proses kegiatan yang sedang berjalan maupun terhadap hasil yang dicapai dari kegiatan tersebut; (3) Tindakan pengawasan berakhir dengan tindakan disusunnya evaluasi akhir terhadap kegiatan yang dilaksanakan serta pencocokan hasil yang dicapai dengan rencana sebagai tolak ukurnya; (4) Untuk selanjutnya tindakan pengawasan akan diteruskan dengan tindak lanjut baik secara administratif maupun secara yuridis.

Kewenangan merupakan substansi dari asas legalitas. Menurut teori, wewenang diartikan sebagai kemampuan untuk melakukan tindakantindakan hukum tertentu. Pelimpahan wewenang dibagi menjadi 3 bentuk, yaitu: (1) Atribusi, atribusi kewenangan terjadi apabila pendelegasian kekuasaan itu didasarkan pada amanat suatu konstitusi dan dituangkan dalam suatu peraturan pemerintah, tetapi tidak didahului oleh suatu pasal dalam undang-undang untuk diatur lebih lanjut; (2) Delegasi, delegasi mengandung arti penyerahan wewenang dari pejabat yang lebih tinggi kepada yang lebih rendah. Penyerahan demikian tidak dapat dibenarkan selain dengan atau berdasarkan kekuatan hukum. Delegasi selalu dituntut adanya dasar hukum sebab apabila pemberi delegasi ingin menarik kembali wewenang yang telas didelegasikannya, maka harus dengan peraturan perundang-undangan yang sama; (3) Mandat, mandat mengenai kewenangan penguasaan diartikan dengan pemberian kuasa (biasanya bersamaan dengan perintah) oleh alat perlengkapan pemerintah yang memberi wewenang ini kepada yang lain, yang akan melaksanakannya atas nama tanggung jawab alat pemerintah yang pertama tersebut. ${ }^{2}$

Berdasarkan unsur pengawasan yang pertama sebagaimana dikemukakan oleh Muchsan yaitu adanya kewenangan yang jelas yang dimiliki oleh aparat pengawas dikaitkan dengan teori pelimpahan wewenang untuk kemudian didialogkan dengan data 1 , data 2 dan data 3 maka dapat diinterpretasikan bahwa DPRD baik provinsi maupun kabupaten/kota berperan sebagai lembaga perwakilan rakyat di daerah yang memiliki kewenangan untuk melakukan pengawasan terhadap pelaksanaan perda. Wewenang pengawasan yang dimiliki oleh DPRD bersumber pada peraturan perundang-undangan yang dituangkan secara eksplisit, sehingga dikategorikan kedalam pelimpahan wewenang secara atribusi.

Menurut unsur pengawasan yang kedua yaitu adanya suatu rencana yang mantap sebagai alat penguji terhadap pelaksanaan suatu tugas yang akan diawasi, apabila dengan teori pengawasan Robert J. Mokler dan didialogkan dengan data 1, data 2, dan data 3 maka dapat diinterpretasikan bahwa pengawasan pelaksanaan perda oleh DPRD provinsi dan kabupaten/kota lebih mengutamakan bersifat insidental manakala terdapat laporan dan/atau pengaduan dari masyarakat, sedangkan pengawasan yang dibuat secara terencana dan terjadwal hanyalah pengawasan pada masa reses yang telah diagendakan sebelumnya oleh Badan Musyawarah untuk tiap tahun anggaran.

Unsur pengawasan yang ketiga menurut Muchsan adalah tindakan pengawasan dapat dilakukan terhadap suatu proses kegiatan yang sedang berjalan maupun terhadap hasil yang dicapai, apabila didialogkan dengan data 1 , data 2 , dan data 3 maka dapat diinterpretasikan bahwa pengawasan terhadap pelaksanaan perda di Indonesia secara umum meliputi pengawasan yang dilaksanakan pada saat perda dilaksanakan dan terhadap hasil yang telah dicapai. Pengawasan dilaksa-

\footnotetext{
2 Kartika, Op.cit. hlm.18-20.
} 
nakan setiap saat apabila terdapat aduan/laporan dari masyarakat dan inisiatif dari anggota dewan untuk melakukan sidak. Pengawasan terhadap hasil yang dicapai dilaksanakan melalui kunjungan anggota dewan pada masa reses serta evaluasi dalam sidang paripurna DPRD.

Unsur pengawasan selanjutnya adalah tindakan pengawasan berakhir dengan tindakan disusunnya evaluasi akhir terhadap kegiatan yang dilaksanakan serta pencocokan hasil yang dicapai dengan rencana sebagai tolak ukurnya, apabila didialogkan dengan data 1, data 2 dan data 3 maka dapat diinterpretasikan bahwa evaluasi terhadap pengawasan pelaksanaan perda oleh DPRD provinsi dan kabupaten/kota adalah evaluasi akhir berupa laporan secara umum dan menyeluruh dalam rapat paripurna.

Unsur pengawasan terakhir adalah tindakan pengawasan akan diteruskan dengan tindak lanjut baik secara administratif maupun secara yuridis, apabila didialogkan dengan data 1 maka dapat diinterpretasikan bahwa pengawasan terhadap pelaksanaan perda yang dilakukan oleh DPRD Provinsi Sumatera Utara, ditindaklanjuti hanya sebatas rapat dengar pendapat umum, kunjungan kerja, dan rapat kerja alat kelengkapan DPRD dengan mitra kerja, akan tetapi tidak nampak secara jelas adanya tindak lanjut secara administrasi maupun yuridis.

Apabila unsur pengawasan di atas didialogkan dengan data 2, maka dapat diinterpretasikan bahwa tindak lanjut dari pengawasan pelaksanaan perda oleh DPRD Kabupaten Banyumas lebih nyata yaitu melalui tindakan administrasi berupa teguran atau revisi perda (legislatif review). Tindakan administrasi dilakukan sesuai dengan sejauh mana penyimpangan pelaksanaan perda dilakukan.

Unsur pengawasan tersebut di atas jika didilogkan dengan data 3 , maka dapat diinterpretasikan bahwa tindak lanjut dari pengawasan DPRD Provinsi DIY terhadap pelaksanaan perda berupa tindakan administratif meliputi pemberian rekomendasi, permintaan kepada gubernur untuk melakukan perbaikan kebijakan, perubahan, peng- gantian kebijakan, dan/atau teguran terhadap aparat pelaksana dengan kinerja yang tidak efisien efektif.

Berdasarkan teori penggolongan pengawasan menurut segi pelaksanaannya jika didialogkan dengan data 1 , data 2 , dan data 3 maka dapat diintepretasikan bahwa pengawasan terhadap pelaksanaan perda yang dilakukan oleh DPRD merupakan pengawasan represif yakni setelah perda berlaku efektif dalam masyarakat. Sedangkan berdasarkan teori penggolongan pengawasan menurut subyeknya, apabila didialogkan dengan data 1 , data 2, dan data 3 maka dapat diintepretasikan bahwa pengawasan yang dilaksanakan oleh DPRD terhadap pelaksanaan perda termasuk dalam pengawasan legislatif (wasleg). Berdasarkan teori penggolongan pengawasan menurut cara melaksanakannya apabila didialogkan dengan data 1 , data 2, dan data 3 maka dapat diintepretasikan bahwa pengawasan terhadap pelaksanaan perda yang dilakukan oleh DPRD termasuk dalam pengawasan langsung dan tidak langsung sebab pengawasan dilakukan dalam bentuk inspeksi langsung di lapangan serta pengawasan laporan hasil evaluasi.

Berdasarkan uraian di atas nampak bahwa pengaturan mengenai pengawasan pelaksanaan peraturan daerah (perda) oleh DPRD tersebar dalam beberapa peraturan perundang-undangan yaitu Pasal 42 ayat (1) huruf c UU No. 32 Tahun 2004 tentang Pemerintahan Daerah, Pasal 293 dan Pasal 344 UU No. 27 Tahun 2009 tentang Majelis Permusyawaratan Rakyat, Dewan Perwakilan Rakyat, Dewan Perwakilan Daerah, dan Dewan Perwakilan Rakyat Daerah, Pasal 3 Peraturan Pemerintah No. 16 Tahun 2010 tentang Pedoman Penyusunan Peraturan Dewan Perwakilan Rakyat Daerah tentang Tata Tertib Dewan Perwakilan Rakyat Daerah, yang kemudian diturunkan lagi menjadi peraturan tata tertib dalam masing-masing DPRD provinsi maupun DPRD kabupaten/kota. Pengaturan pengawasan pelaksanaan perda oleh DPRD dapat penulis gambarkan dalam bagan di bawah ini: 
UU No. 32 Tahun 2004 Ps. 42 Ayat (1) huruf $c$

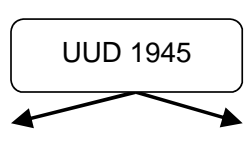

UU No. 27 Tahun 2009 Ps. 293 dan 344

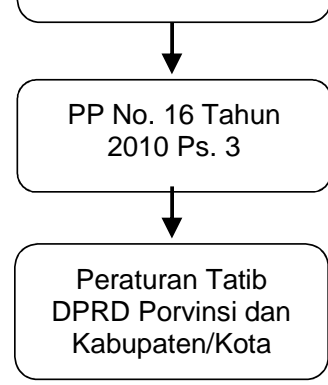

Gambar 8: Bagan dasar hukum pengawasan DPRD

Pembicaraan mengenai taraf sinkronisasi tidak akan terlepas dari teori jenjang norma (Stufentheorie) yang dikemukakan oleh Hans Kelsen bahwa norma hukum itu berjenjang-jenjang dan berlapis-lapis dalam suatu hierarki tata susunan, dimana suatu norma yang lebih rendah berlaku, bersumber dan berdasarkan pada norma yang lebih tinggi, demikian seterusnya sampai pada suatu norma yang tidak dapat ditelusur lebih lanjut dan bersifat hipotesis dan fiktif, yaitu norma dasar (Groundnorm).

Hans Nawiasky kemudian mengembangkan teori jenjang norma yang dikemukakan oleh Hans kelsen. Nawiasky berpendapat bahwa selain berlapis-lapis, norma hukum dalam suatu negara juga berkelompok-kelompok, yang terbagi menjadi empat kelompok besar yaitu Staatsfundamentalnorm (norma fundamental Negara), Staatsgrundgesetz (aturan dasar/pokok Negara), Formell gesetz (Undang-Undang), dan Verordenung dan Autonome Satzung (aturan pelaksana dan aturan otonom).

Jenis dan hierarki Peraturan perundang-undangan di Indonesia berdasarkan Pasal 7 ayat (1) UU No 12 tahun 2011 tentang Pembentukan Peraturan Perundang-undangan, sebagai berikut: (a) Undang-Undang Dasar Negara Republik Indonesia Tahun 1945; (b) Ketetapan Majelis Permusyawaratan Rakyat; (c) Undang-Undang/Peraturan Pemerintah Pengganti Undang-Undang; (d) Peraturan Pemerintah; (e) Peraturan Presiden; (f) Pe- raturan Daerah Provinsi; dan (g) Peraturan Daerah Kabupaten/kota.

DPRD provinsi Sumatera Utara dalam melaksanakan fungsi pengawasan berpedoman pada Peraturan DPRD provinsi Sumatera Utara No. 5 tahun 2010 tentang Perubahan Peraturan DPRD Provinsi Sumatera Utara No. 1/K/2010 tentang Tata Tertib DPRD Provinsi Sumatera Utara, yang dalam Pasal 5 ayat (3) menyebutkan bahwa DPRD provinsi Sumatera Utara melaksanakan pengawasan terhadap pelaksanaan, Perda, APBD, Peraturan Gubernur dan kebijakan yang ditetapkan oleh Pemerintah Daerah.

Ketentuan Pasal 5 ayat (3) Peraturan DPRD provinsi Sumatera Utara No. 5 Tahun 2010 tersebut apabila diintepretasikan terhadap teori jenjang norma dari Hans Kelsen maka termasuk dalam norma hukum. Jika diinterpretasikan terhadap teori Hans Nawiaski masuk dalam kelompok aturan pelaksana (Verordenung). Jika dikaitkan dengan hierarki norma hukum Pasal 7 ayat (1) UU No. 12 Tahun 2011 maka termasuk dalam Perda Provinsi.

Peraturan tata tertib DPRD provinsi Sumatera Utara No. 5 Tahun 2010 tersebut bersumber pada Pasal 3 Peraturan Pemerintah No. 16 Tahun 2010, yang apabila ditarik ke atas maka mengacu pada Pasal 293 UU No. 27 Tahun 2009 serta mengacu pula pada Pasal 42 ayat (1) huruf c UndangUndang No. 32 Tahun 2004, sampai dengan norma dasarnya yaitu Pasal 20 A ayat (1) UUD 1945. Keseluruhan norma tersebut mulai dari tingkatan jenjang norma terendah hingga norma dasar (groundnorm) yang membentuknya, memiliki keterkaitan dan sinkronisasi secara vertikal.

DPRD Kabupaten Banyumas dalam melaksanakan fungsi pengawasan berpedoman pada Peraturan DPRD Kabupaten Banyumas No. 1 tahun 2010 tentang Tata Tertib DPRD Kabupaten Banyumas, yang dalam Pasal 3 huruf c menyebutkan bahwa DPRD Kabupaten Banyumas melaksanakan pengawasan terhadap pelaksanaan Peraturan Daerah, APBD, Peraturan Gubernur, Keputusan Gubernur dan peraturan perundang-undangan lainnya, serta kebijakan yang ditetapkan oleh 
Pemerintah, Pemerintah Daerah dalam melaksanakan program pembangunan Daerah.

Ketentuan Pasal 3 huruf c Peraturan DPRD Kabupaten Banyumas No. 1 Tahun 2010 tersebut apabila diintepretasikan terhadap teori jenjang norma dari Hans Kelsen maka termasuk dalam norma hukum. Jika diinterpretasikan terhadap teori Hans Nawiaski masuk dalam kelompok aturan pelaksana (Verordenung). Jika dikaitkan dengan hierarki norma hukum Pasal 7 ayat (1) UU No. 12 Tahun 2011 maka termasuk dalam Peraturan Daerah Kabupaten/kota.

Peraturan tata tertib DPRD Kabupaten Banyumas No. 1 Tahun 2010 tersebut bersumber pada Pasal 3 Peraturan Pemerintah No. 16 Tahun 2010, yang apabila ditarik ke atas maka mengacu pada Pasal 344 UU No. 27 Tahun 2009 serta mengacu pula pada Pasal 42 ayat (1) huruf c UU No. 32 Tahun 2004, sampai dengan norma dasarnya yaitu Pasal 20 A ayat (1) UUD 1945. Keseluruhan norma tersebut mulai dari tingkatan jenjang norma terendah hingga norma dasar (groundnorm) yang membentuknya, memiliki keterkaitan dan sinkronisasi secara vertikal.

DPRD provinsi Daerah Istimewa Yogyakarta (DIY) dalam melaksanakan fungsi pengawasan berpedoman pada Peraturan DPRD provinsi DIY No. 1 Tahun 2010 tentang Tata Tertib DPRD Provinsi Sumatera Utara, yang dalam Pasal 5 huruf c menyebutkan bahwa DPRD provinsi DIY melaksanakan pengawasan terhadap pelaksanaan Perda, APBD, Peraturan Gubernur, Keputusan Gubernur dan peraturan perundang-undangan lainnya, serta kebijakan yang ditetapkan oleh Pemerintah, Pemerintah Daerah dalam melaksanakan program pembangunan Daerah.

Ketentuan Pasal 5 huruf c Peraturan DPRD provinsi DIY No. 1 Tahun 2010 tersebut apabila diinterpretasikan terhadap teori jenjang norma dari Hans Kelsen maka termasuk dalam norma hukum. Jika diinterpretasikan terhadap teori Hans Nawiaski masuk dalam kelompok aturan pelaksana (Verordenung). Jika dikaitkan dengan hierarki norma hukum Pasal 7 ayat (1) UU No 12 Tahun 2011 maka termasuk dalam Peraturan Daerah Provinsi.
Peraturan tata tertib DPRD provinsi Sumatera Utara No. 5 Tahun 2010 tersebut bersumber pada Pasal 3 Peraturan Pemerintah No. 16 Tahun 2010, yang apabila ditarik ke atas maka mengacu pada Pasal 293 UU No. 27 Tahun 2009 serta mengacu pula pada Pasal 42 ayat (1) huruf c UU No. 32 Tahun 2004, sampai dengan norma dasarnya yaitu Pasal 20 A ayat (1) UUD 1945. Keseluruhan norma tersebut mulai dari tingkatan jenjang norma terendah hingga norma dasar (groundnorm) yang membentuknya, memiliki keterkaitan dan sinkronisasi secara vertikal.

Pengaturan mengenai pengawasan pelaksanaan perda oleh DPRD baik provinsi maupun kabupaten/kota dalam tataran Undang-Undang tidak hanya bersumber pada satu Undang-Undang saja melainkan mengacu pada dua Undang-Undang yakni UU No. 32 Tahun 2004 tentang Pemerintahan Daerah dan UU No. 27 Tahun 2009 tentang MPR, DPR, DPD, dan DPRD. Menilik ketentuan Pasal 42 ayat (1) huruf $c$ UU No. 32 Tahun 2004 disebutkan bahwa DPRD mempunyai tugas dan wewenang untuk melaksanakan pengawasan terhadap pelaksanaan perda dan peraturan perundang-undangan lainnya, peraturan Kepala Daerah, APBD, kebijakan pemerintah daerah dalam melaksanakan program pembangunan daerah dan kerjasama internasional di daerah.

Undang-Undang No 27 Tahun 2009 mengenai pengawasan oleh DPRD dibagi menjadi dua Pasal yaitu Pasal 293 mengatur pengawasan DPRD provinsi dan Pasal 344 mengatur pengawasan oleh DPRD kabupaten/kota. Pasal 293 ayat (1) huruf c UU No. 27 Tahun 2009 menyebutkan bahwa DPRD provinsi mempunyai tugas dan wewenang untuk melaksanakan pengawasan terhadap pelaksanaan peraturan daerah dan anggaran pendapatan dan belanja daerah provinsi. Pasal 344 ayat (1) huruf c Undang-Undang Nomor 27 Tahun 2009 menentukan bahwa DPRD kabupaten/kota mempunyai tugas dan wewenang untuk melaksanakan pengawasan terhadap pelaksanaan peraturan daerah dan anggaran pendapatan dan belanja daerah kabupaten/kota. 
Berdasarkan materi muatan yang terkandung dalam ketentuan Pasal 42 ayat (1) huruf c UU No. 32 Tahun 2004 apabila didialogkan dengan ketentuan Pasal 293 ayat (1) huruf c dan Pasal 344 ayat (1) huruf c UU No. 27 tahun 2009 maka terdapat keterkaitan dan sinkronisasi materi muatan pengawasan oleh DPRD baik provinsi maupun kabupaten kota terhadap pelaksanaan peraturan daerah secara horisontal dalam derajat peraturan perundang-undangan yang sama.

Salah satu tugas dan wewenang yang diamanatkan oleh UU No. 32 Tahun 2004 sebagaimana telah diubah terakhir dengan UU No. 12 Tahun 2008 tentang Pemerintahan Daerah Pasal 42 ayat (1) huruf $c$ adalah tugas dan wewenang DPRD untuk melaksanakan pengawasan terhadap peraturan daerah dan peraturan perundang-undangan lainnya, peraturan kepala daerah, Anggaran Pendapatan dan Belanja Daerah, kebijakan pemerintah daerah dalam melaksanakan program pembangunan daerah dan kerjasama internasional di daerah. Pelaksanaan pengawasan oleh DPRD melekat pada hak-hak DPRD yaitu hak menyatakan pendapat, hak angket dan hak interpelasi sebagaimana ditentukan dalam Pasal 43 UU No. 32 Tahun 2004.

Berdasarkan data di atas jika dikaitkan dengan dasar pemikiran dari pengawasan yang diatur dalam UU No. 32 Tahun 2004, dapat diinterpretasikan bahwa konsep pengawasan menurut UU No. 32 Tahun 2004 adalah proses kegiatan yang ditujukan untuk menjamin agar pemerintahan daerah berjalan sesuai dengan rencana dan ketentuan peraturan perundang-undangan yang berlaku. Objek dari pelaksanaan pengawasan oleh DPRD cukup luas yakni segala bentuk penyelenggaraan urusan pemerintahan, namun utamanya adalah pengawasan terhadap peraturan daerah, peraturan kepala daerah dan APBD. Konsep pengawasan disini hanya sebatas mencocokkan antara peraturan daerah dan/atau peraturan perundangundangan di daerah lainnya dengan pelaksanaannya di lapangan, hanya saja dalam UU No. 32 Tahun 2004 tidak diatur secara jelas mengenai mekanisme pelaksanaan pengawasan oleh DPRD serta langkah korektif yang dapat diambil dari hasil evaluasi pelaksanaan pengawasan tersebut.

Apabila dicermati dalam dasar pemikiran pengawasan yang diatur UU No. 32 tahun 2004, telah disebutkan bahwa untuk mengoptimlkan pengawasan maka pemerintah dapat menerapkan sanksi kepada penyelenggara pemerintahan daerah apabila terjadi penyimpangan dan pelanggaran. Sanksi dapat berupa penataan kembali daerah otonom, pembatalan pengangkatan pejabat, penangguhan dan pembatalan berlakunya suatu kebijakan daerah dan ketentuan lain yang ditetapkan daerah, serta dapat menjatuhkan sanksi pidana sesuai dengan peraturan perundang-undangan yang berlaku. Nampak bahwa sejatinya pembuat undang-undang memberikan peluang untuk dapat diterapkannya sanksi oleh terhadap aparat penyelenggara pemerintahan di daerah manakala terjadi pelanggaran, disini wenang penjatuhan sanksi diberikan kepada lembaga eksekutif, sedangkan terhadap pengawasan yang dilakukan oleh DPRD pengaturannya sumir bahkan boleh dikatakan tidak ada aturan yang menyebutkan secara tegas bahwa DPRD berwenang menjatuhkan sanksi manakala terjadi ketidaksesuaian/pelanggaran dalam pelaksanaan perda.

Sejalan dengan Pasal 42 ayat (1) huruf c UU No. 32 Tahun 2004, dalam Pasal 293 ayat (1) huruf c UU No. 27 Tahun 2009 disebutkan bahwa DPRD Provinsi melaksanakan pengawasan terhadap pelaksanaan peraturan daerah dan anggaran pendapatan dan belanja daerah Provinsi, sedangkan dalam Pasal 344 ayat (1) huruf $c$ menentukan bahwa DPRD Kabupaten/Kota melaksanakan pengawasan terhadap pelaksanaan peraturan daerah dan anggaran pendapatan dan belanja daerah Kabupaten/Kota. Pelaksanaan pengawasan melekat dalam hak-hak DPRD sebagaimana diatur dalam Pasal 298 UU No. 27 Tahun 2009 bagi DPRD Provinsi dan Pasal 349 UU No. 27 Tahun 2009 bagi DPRD Kabupaten/Kota.

Berdasarkan data di atas dapat diinterpretasikan bahwa konsep pengawasan dalam UU No. 27 Tahun 2009 hampir sama dengan konsep pengawasan yang diatur dalam UU No. 32 Tahun 
2004, hanya saja dalam UU No. 27 tahun 2009 lebih dipertegas bahwa DPRD Provinsi dan DPRD Kabupate/Kota memiliki tugas dan wewenang untuk melakukan pengawasan terhadap pelaksanaan perda dan APBD baik Provinsi maupun Kabupaten/Kota. Namun terkait dengan mekanisme pengawasan, siapa yang melaksanakan tugas pengawasan, dan bagaimana tindak lanjut dari proses pengawasan yang telah dilaksanakan belum diatur dan dijabarkan dalamnya.

Kemudian lebih lanjut dalam Peraturan Pemerintah No. 16 tahun 2010 tentang Pedoman Penyusunan Peraturan Dewan Perwakilan Rakyat Daerah tentang Tata Tertib Dewan Perwakilan Rakyat Daerah, yang dalam Pasal 2 ayat (4) menentukan bahwa fungsi pengawasan DPRD diwujudkan dalam mengawasi pelaksanaan perda dan APBD, selanjutnya diperjelas dalam Pasal 3 huruf c Peraturan Pemerintah No. 16 Tahun 2010 yang menyebutkan bahwa tugas dan wewenang DPRD adalah melaksanakan pengawasan terhadap pelaksanaan perda dan APBD.

Berdasarkan data di atas dapat diinterpretasikan bahwa konsep pengawasan yang diatur dalam Peraturan Pemerintah No. 16 Tahun 2010, dapat dikategorikan kedalam konsep pengawasan yang sempit, sebab pengawasan dimaknai sebagai proses mencocokan antara peraturan yang berlaku dengan pelaksanaannya dilapangan. Namun dalam Peraturan Pemerintah No. 16 Tahun 2010 lebih diperjelas mengenai subjek yang melaksanakan pengawasan dan objek dari pengawasan. Subjek pengawasan adalah anggota DPRD secara individu dan komisi-komisi dalam DPRD sebagai alat kelengkapan DPRD. Komisi menjadi garda terdepan dalam pelaksanaan fungsi pengawasan oleh DPRD, dimana pengawasan dilakukan sesuai dengan pembagian bidang tugas masing-masing komisi. Pembagian bidang tugas pada masingmasing komisi dimaksudkan untuk mempermudah pelaksanaan pengawasan mengingat ruang lingkup pengawasan yang luas, sehingga diharapkan terjadi koordinasi yang baik dalam pelaksanan kerja secara optimal.
Selain Komisi, dalam pelaksanaan fungsi pengawasan khususnya terkait pengawasan pelaksanaan perda, maka diperlukan pula optimalisasi peran Badan Musyawarah. Telah disebutkan di atas bahwa Badan Musyawarah bertugas mengagendakan seluruh kegiatan yang akan dilaksanakan oleh DPRD untuk tiap tahun anggaran, mengingat pengawasan yang baik dipengaruhi oleh sistem perencanaan yang baik pula. Badan Musyawarah seyogyanya dapat mengagendakan pelaksanaan pengawasan yang terjadwal bukan hanya pengawasan insidental. Pengawasan secara terjadwal yang maksud adalah Badan Musyawarah membuat penjadwalan secara kontinyu untuk mereview seluruh perda yang sedang berlaku apakah masih berlaku efektif dan sesuai dengan peraturan perundang-undangan yang sederajat atau peraturan perundang-undangan yang memiliki derajat lebih tinggi.

Pelaksanaan fungsi pengawasan DPRD salah satunya melalui hak-hak DPRD yakni hak menyatakan pendapat, hak angket dan hak interpelasi sebagaimana ditentukan dalam Pasal 9 Peraturan Pemerintah No. 16 Tahun 2010, sedangkan alat pengawasan yang lain berupa tindak lanjut dari pengaduan masyarakat meliputi rapat dengar pendapat umum, rapat dengar pendapat, kunjungan kerja, atau rapat kerja DPRD dengan mitra kerjanya sebagaimana ditentukan dalam Pasal 116 ayat (5) Peraturan Pemerintah No. 16 tahun 2010. Berdasarkan uraian di atas maka metode pengawasan yang tepat digunakan adalah metode pengawasan secara langsung dan tidak langsung, dengan konsep pengawasan luas, sehingga pengawasan dapat dijalankan secara efektif dan efisien.

\section{Penutup \\ Simpulan}

Pengawasan yang dilakukan oleh DPRD Provinsi dan Kabupaten/Kota terhadap pelaksanaan Peraturan Daerah berdasarkan UU No. 32 Tahun 2004 menggunakan konsep pengawasan dalam arti sempit yang hanya menitikberatkan pada pencocokan antara peraturan dengan pelak- 
sanaannya dilapangan. Sarana yang digunakan DPRD dalam melaksanakan pengawasan terhadap pelaksanaan perda secara umum melalui pelaksanaan hak-hak DPRD, pelaksanaan konsultasi, Penerimaan pengaduan dan aspirasi masyarakat. Belum terdapat pengaturan yang jelas mengenai parameter pengawasan, mekanisme pengawasan dan tindakan korektif dari hasil evaluasi pelaksanaan pengawasan oleh DPRD.

Konsep pengawasan yang tepat diterapkan terhadap pelaksanaan Perda pada masa datang adalah pengawasan dalam arti luas, yang tidak hanya mengacu pada pencocokan aturan dengan pelaksanaannya di lapangan, mencakup unsur korektif baik secara administrasi maupun yuridis.

\section{Saran}

Mengubah konsep pengawasan sempit yang dianur oleh UU No. 32 Tahun 2004, UU No. 27 Tahun 2009, dan Peraturan Pemerintah No. 16 Tahun 2010, menjadi konsep pengawasan luas, agar nantinya hasil dari pelaksanaan pengawasan perda oleh DPRD menjadi nyata (adanya tindakan korektif). 